\title{
Covariates of repeat tourism: an endogenous switching Poisson model
}

\author{
A. GeOrge AssaF \\ Isenberg School of Management, University of Massachusetts-Amberst, Amberst, \\ MA 01003,USA.E-mail: assaf@bt.umass.edu.
}

CARlos PESTANA BARRos

Instituto Superior de Economia e Gestão, Technical University of Lisbon; Rua Miguel Lupi 20, 1249-078 Lisbon, Portugal, and UECE (Research Unit on Complexity and Economics),Lisbon, Portugal.E-mail: cbarros@iseg.utl.pt. (Corresponding autbor.)

\section{LUIZ PINTO MACHADO}

Escola Profissional de Hotelaria e Turismo, Madeira, Portugal. E-mail:luiz.machado@madeira-edu.pt.

\begin{abstract}
This paper introduces the endogenous switching Poisson model to analyse the underlying reasons behind repeat visitation to Madeira Island. The advantage of the model is that it allows for both unobserved heterogeneity and endogeneity in the covariates. Using data gathered by questionnaire, the authors confirm that the overall fit of the model is good and outperforms other related count data models. From the model estimation it is clear that the number of visits to Madeira Island is supported by multiple variables such as destination attributes, hotel facilities and travel cost, tourist motivation and tourist satisfaction. The related policy implications are derived.
\end{abstract}

Keywords: repeat visitation; endogenous switching Poisson model; destination attributes; tourist motivation; tourist satisfaction; destination management

Repeat visitation is often considered a direct reflection of the quality and management of a particular destination (Oppermann, 1997, 1998, 2000; Alegre and Juaneda, 2006; Hong et al, 2009). Repeat tourists are generally those who are satisfied with the destination (Kozak, 2001), insensitive to price (Alegre and Juaneda, 2006), familiar and comfortable with the destination, and who have a positive image of the destination (Milman and Pizam, 1995; Hong et al, 2009). The motivation behind repeat visitation has recently been analysed by a variety of models, including the mixed logit (Correia et al, 2007); the binary 
logit (Alegre and Cladera, 2006); and the normal regression (Alegre and Juaneda, 2006; Kozak, 2001). Generally, there is agreement in the literature that formulating strategies for encouraging repeat visitation starts with a good understanding of the covariates that drive the return of tourists.

In this paper we aim to contribute to the above literature by analysing the sources of repeat visitation to Madeira Island. It is one of Europe's oldest travel locations specializing in sun and sea (Aguiló et al, 2005) and has evolved over different phases with a continuous characteristic: a high number of repeat tourists (Câmara, 2002). We focus on different covariates, including the tourists' nationalities and their socio-demographic characteristics, trip motivation, hotel and travel characteristics, destination attributes, and trip satisfaction. The methodology used in this paper also innovates on other related studies in the literature. We allow for unobserved heterogeneity and endogeneity in the covariates using the endogenous switching Poisson model (Miranda, 2004). Switch signifies that the models split the variables between two groups, characterizing the heterogeneity of the variables. This paper estimates two switch models: one with exogenous variables that characterizes the heterogeneity on the data; and a second with endogenous variables characterizing the endogeneity in the data (Chesher, 1984; McAlister and Pessemier, 1982; McFadden and Train, 2000; Chesher and Santos Silva, 2002; Hong et al, 2009).

The paper proceeds as follows. The next section provides an overview of the literature. The subsequent two sections, respectively, elaborate on the methodology and describe the research design. The final two sections present the results and discussion.

\section{Literature review}

Over the past three decades, the literature has focused extensively on repeat visitation (Mazursky, 1989; Milman and Pizam, 1995; Court and Lupton, 1997; Sônmez and Graefe, 1998; Oh, 1999, Baker and Crompton, 2000; Kozak and Rimmington, 2000; Kozak, 2001; Bigne et al, 2001; Bowen, 2001; Caneen, 2003; Pritchard, 2003; Um et al, 2006). In general, most studies indicate that repeat visitation is positively explained by tourist satisfaction, since a satisfied tourist is more likely to return to a particular destination, or to recommend it to others (Kozak and Rimmington, 2000; Kozak, 2001). The intention to return can also be influenced by motivation factors such as comfort or familiarity with a particular destination (Iso-Ahola and Mannell, 1987, Dunn Ross and Iso-Ahola, 1991). With a more favourable destination image, the likelihood that a visitor will be satisfied with a destination and consider future visits is higher (Ashworth and Goodall, 1988; Cooper et al, 1993; Bigne et al, 2001; Lee et al, 2005). Other factors identified as important in explaining a visitor's intention to return include the attributes and facilities of a particular destination (Woodside and MacDonald, 1984; Barros et al, 2010).

The literature is also rich in terms of the methodologies proposed to analyse repeat visitation. The model used in this paper aims to explain the concept of repeat visitation, as expressed by the number of times a tourist has visited the destination. Our model is part of the choice set models' family, originally 
proposed by Spiggle and Sewall (1987) in the consumer behaviour literature, and introduced to the tourism literature by several studies (Crompton, 1979; Woodside and MacDonald, 1984; Woodside and Lysonski, 1989; Um and Crompton, 1992; Crompton and Ankomah, 1993; Oppermann, 1997, 1998; Kozak and Rimmington, 2000; Petrick et al, 2001; Woodside and Dubelaar, 2002; Sirakaya and Woodside, 2005; Alegre and Cladera, 2006; Alegre and Juaneda, 2006; Chen and Tsai, 2007; Weaver et al, 2007 and Hong et al, 2009).

More in line with the present research, Ledesma et al (2005) used a left truncated Poisson and a binomial logit model to analyse repeat visitation in the island of Tenerife, and Hellström (2006) used an inflated truncated bivariate Poisson log normal model to analyse the households' choice of overnight stays. Other related studies include Palmer-Tous et al (2007) who used several count data models (Poisson, negative binomial, zero-inflated Poisson, zero-inflated negative binomial, truncated Poisson, zero-truncated negative binomial) to analyse the use of hire cars by tourists in Mallorca, Spain, and Moran et al (2006) who also presented several count data models (negative binomial model, zero truncated negative binomial, negative binomial with truncation and endogenous stratification) to estimate the recreational value of mountain biking sites in Scotland. The authors concluded that correcting for endogenous stratification in addition to over-dispersion and truncation is needed to avoid biased results. Hellström (2006) estimated a bivariate count data for tourism demand.

From our review of the literature, it is clear that the endogenous switching Poisson model has not been used before in tourism related studies. This is despite its clear advantage over the traditional Poisson model, particularly as it can account for unobserved heterogeneity and endogeneity in the covariates. This paper also innovates by focusing on Madeira Island (Oliveira and Pereira, 2008; Almeida and Correia, 2010). More details about the methodology and the sample under analysis are provided in the next sections.

\section{Methodology}

The dependent variable in this study is the number of times the interviewed tourist visited Madeira. This variable is a counting variable characterized for being non-negative, and thus should be modelled as a Poisson or a binomial negative model (Cameron and Trivedi, 1998; Greene, 2003). The Poisson model is based on the hypothesis that the endogenous variable $y_{i}$ (counts of the number of visits to Madeira), given the covariates $x$, is independent with the conditional probability function of $n$ :

$$
\operatorname{Pr}(n ; \lambda)=\frac{e^{-\lambda} \lambda^{n}}{n !} \text { for } y=0,1,2 \ldots
$$

where $n$ is the number of occurrences of an event (visits to Madeira) the probability of which is given by the Poisson mass function, $n$ ! (factorial of $n$ ), and $\lambda$ is the shape parameter thatindicates the average number of events (visits) 
in a given time interval. For a sample $K$, the likelihood function of the Poisson distribution is:

$$
L(\lambda)=-n \lambda+\left(\sum_{i=1}^{n} k_{i}\right) \log (\lambda)-\sum_{i=1}^{n} \log (k !) .
$$

The Poisson distribution tends to exhibit over-dispersion, when the observed variance is superior to the theoretical variance. This problem is prevalent in questionnaires with heterogeneous tourists. Under-dispersion can also occur if the observed variance is lower than the theoretical variance. To account for these problems, we use here the endogenous switching model, which was originally considered in Terza (1998).

\section{Research design}

\section{Survey methods}

The study was undertaken in March and April 2008. Tourists departing from Funchal Airport, Madeira, were randomly approached to answer the questionnaire. The interviewer approached the randomly selected tourist while he or she was waiting in the departure lounge to board the flight home. Budgetary restrictions limited the number of questionnaires to 550, assuming a response rate of $80 \%$ and the number of unusable questionnaires of $10 \%$. The number of answered questionnaires obtained was 498, but only 346 were usable, due to errors and incomplete fields, Dillman (1978).

Most of the respondents were male (52\%) with an average age of 33 . On average, they were middle-class, with a family that includes one child. Other characteristics of the sample are summarized in Table 1.

\section{Questionnaire}

Table 1 describes the characteristics of all model variables. Respondents were asked to complete the questionnaire, which included questions concerning tourist nationalities, socio-economic characteristics, trip motivations, hotel and travel characteristics, destinations attributes, and tourist satisfaction. Items described in each of these questions are line with previous studies in the area (Sirakaya et al, 1996; Fodness, 1999). We assessed the importance of each of the above-mentioned attributes (destination) with a five point Likert-type scale. This scale ranged from 'without importance' 1 to 'extremely important' 5 , but was renumbered as a dummy variable $0-1$ due to the fact that Likert is not a normal distribution.

\section{Hypotheses}

To evaluate repeat visitation of tourists in the Madeira - we assume that the repeat visitation can be explained by several factors: the nationalities of the individuals who completed the questionnaire, other socio-demographic characteristics beyond nationality (such as age, education, gender, and social class of the individuals), trip motivation, hotel and travel characteristics, destination attributes, and trip satisfaction. 
Table 1. Variable characteristics.

Variable Description

Min Max Mean SD

Dependent variable

Frequency Number of times a tourist has visited Madeira

$\begin{array}{llll}1 & 9 & 1.150 & 0.702\end{array}$

Nationalities

French Dummy variable which is one if the tourist is $\begin{array}{lllll}\text { French and zero elsewhere } & 0 & 1 & 0.546 & 0.498\end{array}$

UK Dummy variable which is one if the tourist is from UK and zero elsewhere

Spanish Dummy variable which is one if the tourist is

Spanish and zero elsewhere

$0.050 \quad 0.218$

German Dummy variable which is one if the tourist is

German citizen and zero elsewhere

$\begin{array}{llll}0 & 1 & 0.029 & 0.168\end{array}$

$\begin{array}{llll}0 & 1 & 0.027 & 0.163\end{array}$

Socio-demographic characteristics hypothesis

Education Education (number of years of education after primary school)

Age The respondent's age

Gender The gender $(1=$ male, $0=$ female $)$

Marital status Marital status $(1=$ married; $0=$ non-married $)$

$\begin{array}{rrrr}1 & 8 & 3.430 & 1.740 \\ 21 & 72 & 39.87 & 12.78 \\ 0 & 1 & 0.565 & 0.496 \\ 0 & 1 & 0.340 & 0.474\end{array}$

Motivations

Firstmotive What is the main motivation for your trip:

Familiarity with the destination $(0-$ low, 1 - high)

$\begin{array}{llll}0 & 1 & 0.300 & 0.286\end{array}$

Secondmotive What is the main motivation for your trip:

Comfortable with the destination $(0-$ low, 1 - high)

$\begin{array}{llll}0 & 1 & 0.216 & 0.328\end{array}$

Thirdmotive What is the main motivation for your trip:

Positive image of the destination $(0-$ low, 1 - high)

$\begin{array}{llll}0 & 1 & 0.128 & 0.095\end{array}$

Hotel facilities and travel cost

Hotel type What kind of hotel did you reserve (other than $5 / 4$ star)

Travel cost What much did you spend on travel (US\$)?

$\begin{array}{llll}0 & 1 & 0.525 & 0.499\end{array}$

$600 \quad 10,0002,182.71135 .9$

Destination attributes

Landscape What was the importance of landscapes in your decision? (0 - without importance;

1 - extremely important)

$\begin{array}{llll}0 & 1 & 0.113 & 0.091\end{array}$

Nature What was the importance of nature in your decision? $(0-$ without importance;

1 - extremely important)

Climate What was the importance of climate in your decision? (0 - without importance; 1 - extremely important)

$\begin{array}{llll}0 & 1 & 0.450 & 0.042\end{array}$

Sun and sea What was the importance of sun and sea in your decision? $(0-$ without importance;

1 - extremely important)

Security What was the importance of security in your

$\begin{array}{llll}0 & 1 & 0.820 & 0.496\end{array}$ decision? (0 - without importance;

1 - extremely important)

$\begin{array}{llll}0 & 1 & 0.678 & 0.323\end{array}$ 
Table 1 continued.

\begin{tabular}{|c|c|c|c|c|c|}
\hline Variable & Description & Min & Max & Mean & SD \\
\hline Hospitality & $\begin{array}{l}\text { What was the importance of the hospitality in } \\
\text { your decision? }(0 \text { - without importance; } \\
1 \text { - extremely important })\end{array}$ & 0 & 1 & 0.421 & 0.167 \\
\hline \multicolumn{6}{|l|}{ Satisfaction } \\
\hline Satisfaction & $\begin{array}{l}\text { What is your satisfaction with the overall } \\
\text { quality of Madeira island? }(0-\text { not satisfied, } \\
1-\text { highly satisfied })\end{array}$ & 0 & 1 & 0.832 & 0.218 \\
\hline
\end{tabular}

Hypothesis 1 (nationalities): Repeat visitation is affected by the nationality of tourists. Visitors from the same country usually share homogenous cultural tradition that can affect their preferences (Kozak, 2001, 2003). This hypothesis will be measured by the principal tourist nationalities in Madeira: British, German, Dutch, Swedish and French.

Hypothesis 2 (socio-demographic characteristics): Repeat visitation is affected by the tourists' socio-demographic characteristics (for example, age, education, gender and marital status). These variables have been used in previous studies to classify individual tourists (Goodall and Ashworth, 1988; Woodside and Lysonski, 1989; Weaver et al, 1994; Zimmer et al, 1995; Kozak, 2001, 2003). This hypothesis will be tested with the following variables: age, gender and marital status.

Hypothesis 3 (motivation): Repeat visitation is affected by the tourists' preferences (driving forces or motivations). Motivation analysis in tourism is a long-standing focus that has been researched by, among others, Pearce (1982), Dann (1981), Beerli and Martín (2004), March and Woodside (2005), Yoon and Uysal (2005) and Poria et al, (2006). This hypothesis will be tested with the variables firstmotive, secondmotive and thirdmotive.

Hypothesis 4 (botel facilities and travel cost): Repeat visitation is affected by the accommodation characteristics and travel cost. Barros et al (2010) identified these two variables as important attributes of destination choice. This hypothesis will be tested with the variables hotel type and travel cost.

Hypothesis 5 (destination attributes): Repeat visitation is affected by the destination attributes, which can in many cases shape the visitor's experience (Ross, 1993). The experience that arises through tourist enjoyment, may help tourists make comparison with destinations with similar attributes (Fodness, 1994). Such experience might also affect the tourists' return intention (Woodside and MacDonald, 1984; Baker and Crompton, 2000; Kozak and Rimmington, 2000). The variables used to test this hypothesis are: landscape, nature, climate sun and sea, security and hospitality. These variables, if leading to a positive experience, are expected to increase repetition. 
Hypothesis 6 (satisfaction): Repeat visitation is affected by the level of tourists' satisfaction with the destination. Several studies in the literature indicated that positive customer satisfaction results in repeat purchase and positive word of mouth (Oliver, 1980; Taylor and Baker, 1994; Zeithaml et al, 1996, Heung, 1999). In the tourism literature, it is also accepted that satisfaction has a positive influence on the revisit intention (Ross, 1993; Juaneda, 1996; Keane, 1997; Kozak and Rimmington, 2000; Baker and Crompton, 2000; Kozak, 2001; Caneen, 2003; Yoon and Uysal, 2005; Alegre and Cladera, 2006; Um et al, 2006; Rojas and Camarero, 2008), particularly in a highly competitive environment, where tourists are mainly paying for products that are cost effective and lead to high value and satisfaction. The variable used to test this hypothesis is satisfaction.

\section{Results}

Table 2 presents the results of the count models estimated. The reference model is the endogenous switching Poisson (Miranda, 2004). The other count models are estimated for comparison purposes. There is evidence that over-dispersion and unobserved heterogeneity is present in the data. Moreover there are some zeros in the data. Therefore, a zero truncated Poisson was first estimated to account for zeros. Second, an exogenous switching Poisson model was estimated to account for heterogeneity. We concluded that heterogeneity is present based on the significance of sigma parameter in the model with exogenous switching. Finally, an endogenous switching Poisson model was estimated to account for endogeneity. The final endogenous switching statistically significant rho parameter supports the adequacy of the endogenous switching specification. No changes of sign are detected once endogeneity is considered, but we found important differences in the magnitude of the coefficients.

The log-likelihood value of the estimated endogenous switching Poisson model (-279.21) is the lowest among the estimated models, suggesting thus a better fit. The overall fit of the model is reasonably good, with a Wald test of 126.63. The results show that the number of visits to Madeira Island is explained by multiple variables. Some nationalities, such as the British and Germans, are more 'addicted' to Madeira than others. Particular interest resides in satisfaction, which validates previous research in repeat visitation (Oppermann, 2000). Additionally, motivation issues, such as familiarity and comfort with the destination, and the positive image of the destination appear to play a positive role on repeat visitation, validating previous results by Hong et al (2009). Finally, the travel cost is negative and statistically significant in the endogenous switching Poisson, but insignificant in other models, validating MartinezEspiñera et al (2008) but contradicting Alegre and Juaneda (2006). Of particular interest is the switching variable ${ }^{1}$ (firstmotive) that maintains the sign between the exogenous and endogenous models but with a different value. The first equation includes all variables and the second equation includes the constant and second motive. An exclusion restriction for the switch process is suggested by the familiarity with the destination and it is concluded that second motivefamiliarity with the destination is endogenous with repeat visitation, signifying that familiarity with the destination is a choice variable, correlated with 
Table 2. Parameter estimates.

\section{Zero truncated Exogenous switching Endogenous switching Poisson \\ Poisson \\ Poisson}

\begin{tabular}{|c|c|c|c|}
\hline Variables & Coefficients (std error) & Coefficients (std error) & Coefficients (std error) \\
\hline \multirow[t]{2}{*}{ Constant } & 1.023 & -1.533 & 1.040 \\
\hline & $(2.103)$ & $(1.311)$ & $(0.280)^{*}$ \\
\hline \multirow[t]{2}{*}{ French } & 0.017 & 1.182 & 1.016 \\
\hline & $(0.123)$ & $(0.352)^{*}$ & $(0.411)$ \\
\hline \multirow[t]{2}{*}{ UK } & 0.411 & 1.125 & 1.040 \\
\hline & $(0.069)^{*}$ & $(0.070)^{*}$ & $(0.025)^{*}$ \\
\hline \multirow[t]{2}{*}{ Spanish } & 0.792 & 0.832 & 2.525 \\
\hline & $(0.809)$ & $(0.322)$ & $(1.629)$ \\
\hline \multirow[t]{2}{*}{ German } & 0.682 & 1.621 & 0.322 \\
\hline & $(0.051)^{*}$ & $(0.039)^{*}$ & $(0.048)^{*}$ \\
\hline \multirow[t]{2}{*}{ Gender } & 0.035 & 1.322 & 1.088 \\
\hline & $(0.116)$ & $(0.309)^{*}$ & $(0.220)^{*}$ \\
\hline \multirow[t]{2}{*}{ Age } & 0.014 & 0.990 & 0.984 \\
\hline & $(0.009)$ & $(0.012)$ & $(0.010)^{*}$ \\
\hline \multirow[t]{2}{*}{ Education } & 0.082 & 1.025 & 1.089 \\
\hline & $(0.063)$ & $(0.083)^{*}$ & $(0.090)^{*}$ \\
\hline \multirow[t]{2}{*}{ Marital status } & 0.530 & 1.832 & 2.321 \\
\hline & $(0.305)$ & $(0.322)^{*}$ & $(0.551)^{*}$ \\
\hline \multirow[t]{2}{*}{ Firstmotive } & 0.001 & 0.997 & 0.915 \\
\hline & $(0.0002)^{*}$ & $(0.030)$ & $(0.020)^{*}$ \\
\hline \multirow[t]{2}{*}{ Secondmotive } & 0.212 & 0.223 & 0.733 \\
\hline & $(0.075)^{*}$ & $(0.085)^{*}$ & $(0.087)^{*}$ \\
\hline \multirow[t]{2}{*}{ Thirdmotive } & 0.488 & 0.588 & 0.655 \\
\hline & $(0.231)$ & $(0.132)^{*}$ & $(0.183)^{*}$ \\
\hline \multirow[t]{2}{*}{ Hotel type } & 0.120 & 0.815 & 1.073 \\
\hline & $(0.218)$ & $(0.138)^{*}$ & $(0.038)^{*}$ \\
\hline \multirow[t]{2}{*}{ Travel cost } & -0.915 & -0.689 & -0.399 \\
\hline & $(0.328)$ & $(0.305)$ & $(0.031)^{*}$ \\
\hline \multirow[t]{2}{*}{ Landscape } & 0.333 & 0.218 & 0.735 \\
\hline & $(0.069)^{*}$ & $(0.079)^{*}$ & $(0.090)^{*}$ \\
\hline \multirow[t]{2}{*}{ Nature } & 0.225 & 0.716 & 0.711 \\
\hline & $(0.111)$ & $(0.189)^{*}$ & $(0.162)^{*}$ \\
\hline \multirow[t]{2}{*}{ Climate } & 0.216 & 0.967 & 1.075 \\
\hline & $(0.301)$ & $(0.287)^{*}$ & $(0.048)^{*}$ \\
\hline \multirow[t]{2}{*}{ Sun and sea } & 0.884 & 0.721 & 1.408 \\
\hline & $(0.218)^{*}$ & $(0.309)^{*}$ & $(0.208)^{*}$ \\
\hline \multirow[t]{2}{*}{ Security } & 0.421 & 1.037 & 0.525 \\
\hline & $(0.123)^{*}$ & $(0.420)$ & $(0.219)^{*}$ \\
\hline \multirow[t]{2}{*}{ Hospitality } & 0.815 & 0.702 & 0.421 \\
\hline & $(0.036)^{*}$ & $(0.019)^{*}$ & $(0.020)^{*}$ \\
\hline \multirow[t]{2}{*}{ Satisfaction } & 0.139 & 0.021 & 0.032 \\
\hline & $(0.018)^{*}$ & $(0.005)^{*}$ & $(0.008)^{*}$ \\
\hline \multicolumn{4}{|l|}{ Switch } \\
\hline \multirow[t]{2}{*}{ Constant } & _ & -0.521 & -0.418 \\
\hline & & $(0.058)^{*}$ & $(0.056)^{*}$ \\
\hline Firstmotive & - & 0.582 & 0.224 \\
\hline & & $(0.025)^{*}$ & $(0.011)^{*}$ \\
\hline
\end{tabular}


Table 2 continued.

Zero truncated

Poisson

Coefficients (std error)

Variables

Sigma

Rho

Number of respondents

Log likelihood

LR

Wald
Exogenous switching Poisson

Coefficients (std error)

0.321

$(0.030)^{*}$
Endogenous switching

Poisson

Note: *Statistically significant at $1 \%$.

unobservables related to the error term. For example, if familiarity with the destination correlates with repeat visitation, failure to control for this correlation will yield an estimated familiarity with destination effect that is biased down.

\section{Conclusion}

The paper analysed the determinants of repeat visitation to Madeira Island, using several competing count data models. From the results it was clear that Hypothesis 1 is accepted in the context of British and German nationalities, but rejected for the other nationalities. Hypothesis 2 is also accepted as age, education, gender and marital status are positive and statistically significant. Hypothesis 3 is accepted as both hotel type and travel cost are statistically significant and with the correct sign. Similarly, we also accept Hypotheses 4 and 5 as both destination attributes and satisfaction seem to have a positive and significant impact on tourism return.

Thus, it seems clear that future policies in Madeira should focus on upgrading hotel facilities and other destination attributes, and on increasing comfort and the positive image of Madeira. Targeting nationalities that have a significant impact should also be included in a policy to attract desired types of tourists. Thus, by combining and acting on these results, it is clear that there is an opportunity to refine policies to help increase repeat visitation.

How does this paper compare with previous research? While this paper supports some traditional results such as familiarity, comfort (Hong et al, 2009) and satisfaction (Oppermann, 2000), it does not validate the insignificance of price (Alegre and Juaneda, 2006) and supports the idea that endogeneity and heterogeneity exist in repeat visitation. This endogeneity has implications for the setting of managerial practices to increase repeat visitation, since it results in different managerial practices. In the present case, familiarity and repeat visitation are correlated and should be the focus of a target policy, along with all the other exogenous variables that affect repeat visitation. Based on the 
heterogeneity and the endogeneity detected in the sample, the idea of a homogenous tourist population should be abandoned, even for such a destination as Madeira. This result implies that each destination has its own specificity, which thus justifies the existence of several studies.

\section{Endnotes}

1. Switch signifies that a separate equation is specified for each mean model and for each (co)variance model and are endogenous variables estimated taking heterogeneity into account. Therefore switch can signify heterogeneous variables.

\section{References}

Aguiló, E., Alegre, J., and Sard, M. (2005), 'The persistence of the sun and sea tourism model', Tourism Management, Vol 26, pp 219-231.

Alegre, J., and Cladera, M. (2006), 'Repeat visitation in mature sun and sand holiday destinations', Journal of Travel Research, Vol 44, pp 288-297.

Alegre, J., and Juaneda, C. (2006), 'Destination loyalty: consumers' economic behavior', Annals of Tourism Research, Vol 33, pp 684-706.

Almeida, A., and Correia, A. (2010), 'Analysis of development of tourism in Madeira based on the life cycle approach', Tourism Economics, Vol 16, No 2, pp 427-441.

Ashworth, G., and Goodall, B. (1998), 'Tourist images: marketing considerations', in Goodall, B., and Ashworth, G., eds, Marketing in the Tourism Industry. The Promotion of Destination Regions, Croom Helm, London.

Baker, D., and Crompton, J. (2000), 'Quality, satisfaction, and behavioral intentions', Annals of Tourism Research, Vol 27, 785-804.

Barros, C.P., Butler, R., and Correia, A. (2010) ${ }_{2}$ 'The length of stay of golf tourism: a survival analysis', Tourism Management, Vol 31, pp 13-21

Beerli, A., and Martín, J. (2004), 'Tourists' characteristics and the perceived image of tourist destinations: a quantitative analysis - a case study of Lanzarote, Spain', Tourism Management, Vol 25, pp 623-636.

Bigne, J., Sanchez, M., and Sanchez, J. (2001), 'Tourism image, evaluation variables and after purchase behavior: Inter-relationships', Tourism Management, Vol 22, pp 607-616.

Bowen, D. (2001), 'Antecedents of consumer satisfaction and dis-satisfaction(CS/D) on long-haul inclusive tours: a reality check on theoretical considerations', Tourism Management, Vol 22, pp 49-61.

Burns, A.C., and Bush, R.F. (1995), Marketing Research, Prentice Hall, Upper Saddle River, NJ.

Câmara, B. (2002), A Economia da Madeira (1850-1914), Imprensa de Ciências Sociais, Lisbon.

Cameron, A.C., and Trivedi, P.K. (1998), Regression Analysis of Count Data, Cambridge University Press, Cambridge.

Caneen, J.M. (2003), 'Cultural determinants of tourism intention to return', Tourism Analysis, Vol 8, pp 237-242.

Chen, C., and Tsai, D. (2007), 'How destination image and evaluative factors affect behavioral intentions?', Tourism Management, Vol 28, pp 1115-1122.

Chesher, A.D. (1984), 'Testing for neglected heterogeneity', Econometrica, Vol 52, pp 865-872.

Chesher, A.D., and Santos Silva, J.M.C. (2002), 'Taste variation in discrete choice models', Review of Economic Studies, Vol 69, pp 147-168.

Chi, C.G.Q., and Qu, H. (2008), 'Examining the structural relationship of destination image, tourist satisfaction and destination loyalty: Na integrated approach', Tourism Management, Vol 29, pp 624636.

Cooper, C., Fletcher, J., Gilbert, D., and Wanhill, S. (1993), Tourism: Principles and Practice, Pitman Publishing, London.

Correia, A., Santos, C.M., and Barros, C.P. (2007), 'Tourism in Latin America: a choice analysis', Annals of Tourism, Vol 34, pp 610-629.

Court, B., and Lupton, D. (1997), 'Customer portfolio development: modeling destination adopters, inactives, and rejecters', Journal of Travel Research, Vol 36, pp 35-43.

Crompton, J.L. (1979), 'Motivations for pleasure vacation', Annals of Tourism Research, Vol 6, pp 408424. 
Crompton, J.L., and Ankomah, P. (1993), 'Choice set propositions in destination decisions', Annals of Tourism Research, Vol 20, pp 461-476.

Dann, G. (1981), 'Tourist motivation: an appraisal', Annals of Tourism Research, Vol 7, pp 187-219.

Dillman, D.A. (1978), Mail and Telephone Survey: The Total Design Method, Wiley, New York.

Dunn Ross, E.L., and Iso-Ahola, S.E. (1991), 'Sightseeing tourists' motivation and satisfaction', Annals of Tourism Research, Vol 18, pp. 226-237.

Fodness, D. (1994), 'Measuring tourist motivation', Annals of Tourism Research, Vol 21, No 3, pp 555-581.

Fodness, D. (1999), 'A model of tourism information search behavior', Journal of Travel Research, Vol 37, pp 220-230.

Goodall, B., and Ashworth, G. (1988), Marketing in the Tourism Industry. The Promotion of Destination Regions, Croom Helm, London.

Greene, W. (2003), Econometric Analysis, Prentice Hall, Upper Saddle River, NJ.

Hellström, J. (2006), 'A bivariate count data model for household tourism demand', Journal of Applied Econometrics, Vol 21, pp 213-226.

Heung, V.C.S. (1999), 'A study of visitors' evaluation of airport restaurant service quality in Hong Kong', unpublished doctoral dissertation, University of Hong Kong, Hong Kong.

Hong, S.K., Lee, S.W., Lee, S., and Jang, H. (2009), 'Selecting revisited destinations', Annals of Tourism Research, Vol 36, pp 268-294.

Iso-Ahola, S., and Mannell, R. (1987), 'Psychological nature of leisure and tourism experience', Annals of Tourism Research, Vol 14, pp 314-331.

Juaneda, C. (1996), 'Estimating the probability of return visits using a survey of tourist expenditure in the Balearic Islands', Tourism Economics, Vol 2, pp 339-352.

Keane, M.J. (1997), 'Quality and pricing in tourism destinations', Annals of Tourism Research, Vol 24, pp 117-130.

Kozak, M. (2001), 'Repeaters' behavior at two distinct destinations', Annals of Tourism Research, Vol 28, pp 784-807.

Kozak, M. (2003), 'Measuring tourist satisfaction with multiple destination attributes', Tourism Analysis, Vol 7, pp 229-240.

Kozak, M., and Rimmington, M.(2000), 'Tourist satisfaction with Mallorca, Spain as an off-season holiday destination', Journal of Travel Research, Vol 38, pp 260-269.

Ledesma, F.J., Navarro, M., and Perez Rodriguez, J.V. (2005), 'Return to tourist destination. It is reputation after all?', Applied Economics, Vol 37, pp 2055-2065.

Lee, C., Lee, Y., and Lee, B. (2005), 'Korea's destination image formed by the 2002 World Cup', Annals of Tourism Research, Vol 32, pp 839-858.

March, R., and Woodside, A.C. (2005), 'Testing theory of planned versus realized tourism behavior', Annals of Tourism Research, Vol 32, pp 905-924.

Mazursky, D. (1989), 'Past experience and future tourism decisions', Annals of Tourism Research, Vol 16, pp 333-344.

McFadden, D., and Train, K. (2000), 'Mixed MNL models of discrete response', Journal of Applied Econometrics, Vol 15, pp 447-470.

Martinez-Espiñera, R., Loomis, J.B., Amoako-Tuffour, J., and Hilbe, J.M. (2008), 'Comparing recreational benefits from one-site versus household surveys in count data travel cost demand models with overdispersion', Tourism Economics, Vol 14, pp 567-576.

Miranda, A. (2004), 'FIML estimation of an endogenous switching model for count data', Stata Journal, Vol 4, pp 40-49.

McAlister, L., and Pessemier, E. (1982), 'Variety seeking behavior: an interdisciplinary review', Journal of Consumer Research, Vol 9, pp 311-322.

Milman, A., and A. Pizam. (1995), 'The role of awareness and familiarity with a destination: the central Florida case', Journal of Travel Research, Vol 34, pp 21-27.

Moran, D., Tresidder, E.E., and McVittie, A. (2006), 'Estimating the recreational value of mountain biking sites in Scotland using count data models', Tourism Economics, Vol 12, pp 123-135.

Oh, H. (1999), 'Service quality, customer satisfaction, and customer value: a holistic perspective', International Journal of Hospitality Management, Vol 18, pp. 67-82.

Oliveira, P., and Pereira, P.T. (2008), 'Who values what in a tourism destination? The case of Madeira Island', Tourism Economics, Vol 14, pp 155-168.

Oliver, R.L. (1980), 'A cognitive model of antecedents and consequences of satisfaction decisions', Journal of Marketing Research, Vol17, pp 460-469. 
Oppermann, M. (1997), 'First-time and repeat visitors to New Zealand', Tourism Management, Vol 18, pp 177-181.

Oppermann, M. (1998), 'Destination threshold potential and the law of repeat visitation', Journal of Travel Research, Vol 37, pp 131-137.

Oppermann, M. (2000), 'Tourism destination loyalty', Journal of Travel Research, Vol 39, pp 78-84.

Palmer-Tous, T., Riera-Font, A. E., and Rosselló-Nadal, J. (2007), 'Taxing tourism: the case of rental cars in Mallorca', Tourism Management, Vol 28, pp 271-279.

Petrick, J.F., Morais, D.D., and Norman, W.C. (2001), 'An examination of the determinants of entertainment vacationers' intentions to Revisit', Journal of Travel Research, Vol 40, pp 4148.

Pearce, P. (1982), 'Perceived changes in holiday destinations', Annals of Tourism Research, Vol 9, pp 45-164.

Poria,Y., Reichel, A., and Biran, A. (2006), 'Heritage site management, motivations and expectations', Annals of Tourism Research, Vol 33, pp 162-178.

Pritchard, M.P. (2003), 'The attitudinal and behavioral consequences of destination performance', Tourism Analysis, Vol 8, pp 61-73.

Rojas, C., and Camarero, C. (2008), 'Visitors' experience, mood and satisfaction in a heritage context: evidence from an interpretation center', Tourism Management, Vol 29, pp 525-537.

Ross, G.F. (1993), 'Destination evaluation and vacation preferences', Annals of Tourism Research, Vol 20, pp 477-489.

Sirakaya, E., and Woodside, A.G. (2005), 'Building and testing theories of decision making by travelers', Tourism Management, Vol 26, No 6, pp 815-832.

Sirakaya, E., McLellan, R., and Uysal, M. (1996), 'Modeling vacation destination decisions: a behavioral approach', Journal of Travel and Tourism Marketing, Vol 5, pp 57-75.

Spiggle, S., and Sewall, M. (1987), 'A choice sets model of retail selection', Journal of Marketing, Vol 51, pp 97-111.

Sônmez, S.F., and Graefe, A.R. (1998), 'Determining future travel behavior from past travel experience and perceptions of risk and safety', Journal of Travel Research, Vol 37, pp 171177.

Taylor, S.A., and Baker, T. L. (1994), 'An assessment of the relationship between service quality and customer satisfaction in the formation of customers' purchase intentions', Journal of Retailing, Vol 70, pp 163-178.

Terza, J.V. (1998), 'Estimating count data models with endogenous switching: sample selection and endogenous treatment effects', Journal of Econometrics, Vol 84, pp 129-154.

Um, S., and Crompton, J.L. (1992), 'The roles of perceived inhibitors and facilitators in pleasure travel destination decisions', Journal of Travel Research, Vol 30, pp 18-25.

Um, S., Chon, K., and Ro, Y. (2006), 'Antecedents of revisit intention', Annals of Tourism Research, Vol 33, pp 1141-58.

Weaver, P.A., Weber, K., and McCleary, K. (2007), 'Destination evaluation: the role of previous travel experience and trip characteristics', Journal of Travel Research, Vol 45, pp 333-344.

Weaver, P.A., McCleary, K.W., Lepisto, L., and Taylor Damonte, L. (1994), 'The relationship of destination selection attributes to psychological, behavioral and demographic variables', Journal of Hospitality and Leisure Marketing, Vol 2, pp 8-14.

Winkelmann, R. (2008), Econometric Analysis of Count Data, Springer, London.

Woodside, A.G., and MacDonald, R. (1984), 'General system framework of customer choice process of tourism services', in Gasser, R.V., and Weiermair, K., eds, Spoilt for Choice, Kulturverlag Polzer, Thaur, pp 30-59.

Woodside, A.G., and Lysonski, S. (1989), 'A general model of traveler destination choice', Journal of Travel Research, Vol 27, pp 8-14.

Woodside, A.G., and Dubelaar, C. (2002), 'A general theory of tourism consumption systems: a conceptual framework and an empirical exploration', Journal of Travel Research, Vol 41, pp 120 132.

Yoon, Y., and Uysal, M. (2005), 'An examination of the effects of motivation and satisfaction on destination loyalty: a structural model', Tourism Management, Vol 26, pp 45-56.

Zeithaml, V. A., Berry, L.L., and Parasuraman, A. (1996), 'The behavioral consequences of service quality', Journal of Marketing, Vol 60, pp 31-46.

Zimmer, Z., Brayley, R.E., and Searle, M.S. (1995), 'Whether to go and where to go', Journal of Travel Research, Vol 33, pp 3-10. 